\title{
Monitoring the Bacterial and Fungal Biota of Eleven Tobacco Grades Stored at Three Different Locations*
}

\author{
by \\ Richard Villemur ${ }^{1}$, Martine Lacasse ${ }^{2}$, and André Morin ${ }^{2}$ \\ ${ }^{1} 2900$ Beaudoin, Montreal, QC, H4K 2R5 \\ ${ }^{2}$ Imperial Tobacco Canada, 3711 St-Antoine West, Montreal, QC, Canada, H4C 3P6
}

\section{SUMMARY}

Tobacco as many other plants has its own microbiota. There are very few studies determining the evolution of this microbiota during tobacco storage, which may affect the quality of tobacco. Polymerase chain reaction (PCR) combined with denaturing gradient gel electrophoresis (DGGE) were used to determine changes in the microbiota of tobacco during the aging of eleven different tobacco grades stored at three different locations for twelve months. The microbial fraction of these tobacco grades was extracted, and the bacterial $16 \mathrm{~S}$ and the fungal $18 \mathrm{~S}$ ribosomal RNA gene (rDNA) sequences were PCR amplified before being segregated by DGGE. The bacterial complexity of the tobacco grades was represented by DGGE migrating banding profiles that varied between 20 and 30 bands. Some variations in the banding profiles were observed between the tobacco grades, but overall no substantial changes occurred in the bacterial population of the different grades during their storage at different locations. Most of the fungal DGGE profiles were identical and had only one dominating band related to the genus Aspergillus. Bacterial and fungal isolates were also derived from the microbial fractions of the tobacco, and part of their respective $16 \mathrm{~S}$ and $18 \mathrm{~S}$ rDNA sequences were determined. Bacterial isolates belonged to Bacillales and gamma Protobacteria. Fungal isolates belonged to the genus Aspergillus. Our results showed that the bacterial and fungal biota of tobacco are relatively stable throughout 12 months storage time. [Beitr. Tabakforsch. Int. 23 (2009) 368-376]

\section{ZUSAMMENFASSUNG}

Tabak besitzt wie alle Pflanzen eine eigene Mikroflora. Es gibt nur wenige Studien über die Entwicklung der Mikroflora während der Lagerung des Tabaks, die die Qualität des Tabaks beeinflussen könnte. Mit Hilfe der PolymeraseKettenreaktion (PCR) in Kombination mit denaturierender Gradientengelelektrophorese (DGGE) wurde untersucht, ob sich die Mikroflora von 11 Tabakproben, die an drei verschiedenen Orten gelagert wurden, während der einer Lagerung über 12 Monaten ändert. Die mikrobielle Fraktion dieser Tabakproben wurde extrahiert. Die Sequenzen der bakteriellen $16 \mathrm{~S}$ und die $18 \mathrm{~S}$ ribosomalen RNA-Gene (rDNA) der Pilze wurden durch PCR amplifiziert und mittels DGGE getrennt. Die komplexe bakterielle Zusammensetzung der Tabakproben zeigte sich anhand der DGGE Trennprofile, die 20 - 30 Banden aufwiesen. Die gefundenen DGGE-Trennprofile zeigten einige Veränderungen; im allgemeinen ergaben sich jedoch keine wesentlichen Unterschiede in den Bakterienpopulationen während der Lagerung der verschiedenen Tabakproben an drei verschiedenen Orten. Die meisten Pilz-DGGE-Profile waren identisch und zeigten nur eine dominante Bande, die zur Gattung Aspergillus gehört. Es wurden auch Bakterien- und Pilz-Isolate aus den mikrobielelen Fraktionen der Tabake hergestellt und ein Teil ihrer 16S bzw. 18S rDNASequenzen bestimmt. Bakterielle Isolate gehörten zu den Bacillales und gamma-Protobakterien, Pilzisolate gehörten zur Gattung Aspergillus. Unsere Ergebnisse zeigen, dass die Zusammensetzung von Bakterien und Pilzen auf Tabak während der gesamten Lagerzeit relativ unverändert bleibt. [Beitr. Tabakforsch, Int. 23 (2009) 368-376]

*Received: $14^{\text {th }}$ July 2008 - accepted: $4^{\text {th }}$ May 2009 


\section{RESUME}

Le tabac, comme toute autre plante, possède sa propre microflore. Très peu d'études démontrent l'évolution de cette microflore durant l'entreposage du tabac. Ceci peut affecter la qualité du tabac. La réaction de polymérisation en chaîne (PCR) combinée à l'électrophorèse sur gradient de gel dénaturant (DGGE) a été utilisée pour déterminer si des changements survenaient dans la microflore du tabac durant le vieillissement de onze grades différents de tabac entreposés à trois endroits différents durant douze mois. La fraction microbienne de ces grades a été extraite. Ensuite, les séquences des gènes des $\mathrm{ARN}$ ribosomaux ( $\mathrm{rDNA}$ ) bactériens (16S) et fongiques (18S) ont été amplifiées par PCR avant d'être séparées par DGGE. La complexité bactérienne des grades de tabac a été représentée par des profils DGGE de migration variant de 20 à 30 bandes. Quelques variations du profil de migration furent observées entre les grades de tabac. Dans l'ensemble, aucun changement substantiel n'est apparu dans la population bactérienne des différents grades entreposés à différents endroits. La plupart des profils DGGE des moisissures étaient identiques et ne possédaient qu'une bande dominante apparentée au genre Aspergillus. Des souches de bactéries et de moisissures ont aussi été isolées des fractions microbiennes du tabac. Une partie de leurs séquences $16 \mathrm{~S}$ et $18 \mathrm{~S}$ rDNA a été déterminée. Les isolats bactériens appartiennent aux Bacillales et au gamma protéobactéries et les isolats de moisissures appartiennent au genre Aspergillus. Nos résultats démontrent que la microflore bactérienne et fongique du tabac est stable durant douze mois d'entreposage. [Beitr. Tabakforsch. Int. 23 (2009) 368-376]

\section{INTRODUCTION}

A wide variety of microorganisms are living on and in all plants and tobacco has its own microbiota which could affect the quality of tobacco during different storage conditions. Methods currently used to monitor and identify the tobacco microbiota are culture-based methods, but such assessment is incomplete as many microorganisms cannot be cultivated with existing laboratory nutrient media. Thus, in recent years, new techniques developed in molecular biology have emerged and permit analyze of microbiota that are culture-dependent and -independent (1). One of these is the Polymerase Chain Reaction coupled with the Denaturing Gradient Gel Electrophoresis (PCR-DGGE). This method uses PCR amplification of $16 \mathrm{~S}$ or $18 \mathrm{~S}$ ribosomal RNA gene (rDNA) sequences followed by their segregation by denaturing migration through a gel (2). This technique was investigated to define the microbial species involved in the fermentation process of Italian Toscano cigar tobacco (3) and to define the microbiota of aging flue-cured tobacco in China (1). In these two studies, mainly bacterial species were reported to take part in either fermentation (Jeotgalicoccus, Staphylococcus, Aerococcus, Lactobacillus, Weissella, Bacillus, Corynebacterium, Yania) or aging (sweating) (Bacteriovorax sp., Bacillus megaterium). During the early phase of cigar tobacco fermentation, a yeast population developed and was predominated by Debaryomyces hansenii (3). None of these two papers mentioned the occurrence of molds although $D$. hansenii which produces a lethal toxin active against molds was suggested to prevent the outgrowth of molds in the early stages of cigar tobacco fermentation. Aspergillus (e.g. A. repens) and Penicillium species were predominant in damaged flue-cured tobacco (4) but some species of these two genera were also isolated in undamaged tobacco. In laboratory tests, flue-cured tobacco inoculated with Aspergillus repens, was able to support growth of the fungus directly related to increasing moisture content (15-45\%), duration (1-4 weeks) and temperature $\left(20\right.$ and $30{ }^{\circ} \mathrm{C}$ ) of incubation (5).

From farm curing to consumable end product, the moisture content of tobacco varies within a range of 10 to $30 \%$. After farm curing, tobacco may be shipped to different countries where it is stored (aged) for several months or years. Aging of tobacco is usually conducted at a moisture content ranging from 10 to $13 \%$ (6). However, storage conditions may substantially vary between locations. This could induce changes in the microbiota and therefore impact the characteristics of the product. In this report, we compared the bacterial and fungal biota of eleven tobacco grades with various sugar content aged over twelve months at three locations: one in a country with a temperate climate and two in a country with a tropical climate. PCRDGGE was used to monitor the bacterial and fungal biota. Finally, isolates of culturable bacterial and fungal fractions from one tobacco grade were identified.

\section{MATERIALS AND METHODS}

\section{Tobacco storing conditions and sampling}

Eleven grades of Canadian flue cured tobacco, varying in their sugar content, were monitored: low sugar: $\mathrm{X} 2 \mathrm{M}$; medium sugar: $\mathrm{MF} 2 \mathrm{C}, \mathrm{H} 2 \mathrm{M}, \mathrm{X} 1 \mathrm{C}, \mathrm{H} 2 \mathrm{C}$ and high sugar: FS1C, X1, 01, H1, H1M, MF1M. Eleven sample cases, containing $200 \mathrm{~kg}$ of each tobacco grade were stored at location A and used as controls while two series of the eleven cases were sent by truck and stored in location $\mathrm{M}$ and $\mathrm{T}$, respectively. At all locations, tobacco was stored in warehouse at ambient conditions. In all three locations, relative humidity and temperature were monitored and recorded at each sampling time (Fig. 1a). The monthly sampling of tobacco was done as follows. Five hundred grams of tobacco were taken at a minimum of $15 \mathrm{~cm}$ below the top surface of each tobacco case. Sterile gloves were used to sample tobacco to prevent contamination. Initial samples (first month) were taken from cases while still at location A, then two series of the eleven cases were sent to the other two locations (M, T) by ground transportation in unrefrigerated trucks and lasted approximately two weeks. M and T locations have both tropical climate, the first one being more humid while the second one being more dry. Afterwards, samples were taken as close as possible to the 15 th of each month in all locations and sent to Imperial Tobacco Canada in Montreal for analysis. Samples were wrapped in well identified plastic bags and shipped by truck in carton boxes. During the travel, samples were exposed to ambient temperature. 
Samples taken at location A took one day to reach Montreal while samples taken at locations $\mathrm{M}$ and $\mathrm{T}$ took in average three days to reach Montreal.

\section{Physico-chemical parameters of stored tobacco}

Upon receipt, tobacco samples were stored at $4{ }^{\circ} \mathrm{C}$ and processed as follows. Samples of each grade were analyzed for total sugars (7, CV: 4\%) and moisture. The moisture was measured by weighing the tobacco before and after being dried in an oven at $110{ }^{\circ} \mathrm{C}$ for $3 \mathrm{~h}$. For the total sugar content, the tobacco samples were prepared for analysis by grinding until the samples totally passed through a $1 \mathrm{~mm}$ sieve. Five hundred $\mathrm{mg} \pm 1 \mathrm{mg}$ of each ground tobacco sample was weighed in a $125 \mathrm{~mL}$ Erlenmeyer and extracted in $50 \mathrm{~mL}$ of distilled water by shaking for $15 \mathrm{~min}$. The extract was filtered through a Fisherbrand filter paper P8 and the filtrate was collected in a sample cup. The samples were analyzed for total sugars using an Auto Analyzer 3 equipped with a High Resolution Digital Colorimeter 3 from Bran \& Luebbe. To determine the amount of total sugars, the extract was first hydrolyzed to reducing sugars with $\mathrm{HCl}(0.1 \mathrm{~N})$ and by heating the sample with the acid up to $90{ }^{\circ} \mathrm{C}$. Then, the reducing sugars were determined by the reduction of orange hexacyanoferrate III to yellow hexacyanoferrate II and the decrease in color was measured at $420 \mathrm{~nm}$. Working standards of glucose were made from a standard stock solution at $10 \mathrm{mg}$ of glucose per $\mathrm{mL}$. Eight working solutions of glucose were prepared at concentrations covering the range expected to be found in the samples ( 0.25 to $3.0 \mathrm{mg}$ glucose per $\mathrm{mL}$ ). A graph plotting the peak height against the equivalent glucose concentrations was made for all the standard working solutions and the percentage of total sugar (on a dry weight basis) was calculated as follow:

$\%$ Total sugar $(\mathrm{dwb})=\frac{c \times V \times 100}{m} \times \frac{100}{(100-M)}$

$c$ is the sugar concentration, expressed in $\mathrm{mg}$ per $\mathrm{mL}$, obtained from the calibration curve

$V$ is the volume in $\mathrm{mL}$, of the extract prepared (normally $25 \mathrm{~mL}$ )

$m$ is the mass in $\mathrm{mg}$ of the sample $(0.50 \mathrm{~g} \pm 0.01 \mathrm{~g})$

$M$ is the moisture content, expressed as percentage by mass

\section{Analysis of the tobacco microbial biota by cultures}

Twenty grams of each tobacco grade were weighed in Whirl-Pak filter stomacher bags. They were mixed with $250 \mathrm{~mL}$ of sterile Ringer's solution for $10 \mathrm{~min}$ at room temperature. Under aseptic conditions, an aliquot of $50 \mathrm{~mL}$ of the uniformly mixed macerate was transferred into a 50 $\mathrm{mL}$ sterile tube. Using the $50 \mathrm{~mL}$ macerate solution, decimal dilutions ranging from $10^{-1}$ to $10^{-4}$ were prepared into sterile Ringer's solution. Aliquots of $0.5 \mathrm{~mL}$ of the diluted macerates were inoculated in duplicate to Brain Heart Infusion agar (BHI) for bacteria, and Littman Oxgall agar (LOA) and Malt Salt agar (MSA) for fungi. The petri dishes were incubated at room temperature for seven days for fungi and at $30{ }^{\circ} \mathrm{C}$ for $48 \mathrm{~h}$ for bacteria. Colonies with different visual characteristics were picked. Biomass from one to two mL-culture from ten bacterial isolates and seven fungal isolates was centrifuged and used for DNA extraction.

\section{DNA extraction}

The macerate was first centrifuged at $1500 \mathrm{~g}$ for $10 \mathrm{~min}$ to remove foliar debris. The supernatant was centrifuged at $16000 \mathrm{~g}$ for $10 \mathrm{~min}$. The supernatant was discarded and the pellet was washed in $30 \mathrm{~mL}, 15 \mathrm{~mL}$ and $4 \mathrm{~mL}$ of saline solution $(\mathrm{NaCl}, 0,9 \% \mathrm{wt} / \mathrm{vol})$ by successive centrifugations at $16000 \mathrm{~g}$ for $10 \mathrm{~min}$. each. Supernatants were discarded and the pellets were frozen at $-80{ }^{\circ} \mathrm{C}$. The frozen pellets were dispersed in $500 \mu \mathrm{L}$ of TEN buffer $(50 \mathrm{mM}$ Tris- $\mathrm{HCl}$ pH 8.0; 100 mM EDTA pH 8.0, $150 \mathrm{mM} \mathrm{NaCl}$ ). To extract DNA from the fungal and bacterial isolates, the pellet from the one to two-mL culture was dispersed in $500 \mu \mathrm{L}$ of TEN. To all samples, $25 \mu \mathrm{L}$ SDS $20 \%(\mathrm{w} / \mathrm{v}), 250 \mathrm{mg}$ glass bead $0.40-0.50 \mathrm{~mm}$ and $500 \mu \mathrm{L}$ phenol/chloroform/isoamyl alcohol (25:24:1) were then added. The cells were broken with FastPrep homogenizer (Qbiogene, CA, USA) (twice $20 \mathrm{sec}$ at speed 4.0) and put on ice. The homogenate was centrifuged $5 \mathrm{~min}$ at $13000 \mathrm{~g}$. The aqueous phase was extracted with $500 \mu \mathrm{L}$ chloroform/isoamyl alcohol (50:1) and centrifuged $2 \mathrm{~min}$ at $13000 \mathrm{~g}$. The DNA was treated with RNase $(10 \mu \mathrm{g} / \mathrm{mL})$ for $15 \mathrm{~min}$ at room temperature, and precipitated for $15 \mathrm{~min}$ at $20{ }^{\circ} \mathrm{C}$ with ammonium acetate ( $2 \mathrm{M}$ final concentration) and two volumes of ethanol $100 \%$. After centrifugation at $13000 \mathrm{~g}$ for $15 \mathrm{~min}$, the DNA pellet was washed with $70 \%$ ethanol and dissolved in $50 \mu \mathrm{L}$ water.

\section{PCR amplification and sequencing}

$16 \mathrm{~S}$ or $18 \mathrm{~S}$ rDNA sequences were amplified by PCR in a DNA thermal Cycler (Geneamp® PCR System 2700; Applied Biosystems Streetsville, ON, Canada). PCR amplifications were performed in a $50-\mu \mathrm{L}$ reaction volume with $10 \mathrm{mM}$ Tris- $\mathrm{HCl} \mathrm{pH} 9.0,1.5 \mathrm{mM} \mathrm{MgCl}_{2}, 50 \mathrm{mM}$ $\mathrm{KCl}, 20 \mu \mathrm{g}$ bovine serum albumin, $200 \mu \mathrm{M}$ dNTP, 10 pmol of each primer (see Table 1), DNA (tobacco DNA, 100-300 ng; isolate DNA, 5-10 ng) and 2.5 U of Taq DNA polymerase (Amersham-Pharmacia Biotech, Baie d'Urfé, QC, Canada). Amplifications were done at $94{ }^{\circ} \mathrm{C}$ for $3 \mathrm{~min}, 55^{\circ} \mathrm{C}$ for $3 \mathrm{~min}$, then 30 cycles at $72{ }^{\circ} \mathrm{C}$ for 45 sec, $94{ }^{\circ} \mathrm{C}$ for $45 \mathrm{sec}, 55^{\circ} \mathrm{C}$ for $45 \mathrm{sec}$, and finally an extension period of $10 \mathrm{~min}$ at $72{ }^{\circ} \mathrm{C}$.

One extremity of the PCR products corresponding to the $5^{\prime}$ extremity of the rDNA sequences was sequenced by the "Centre d'innovation Génome Québec et Université McGill" (Montreal, QC, Canada). Sequences were compared in gene databases with BLASTN (National Center for Biotechnology information, http://www.ncbi. nlm.nih.gov) to determine the most probable affiliation.

\section{$D G G E$}

Denaturing gradient gel electrophoresis (DGGE) was done using a D-code system (Bio-Rad Laboratories Ltd., Mississauga, ON) with PCR products (between 100 to 300 


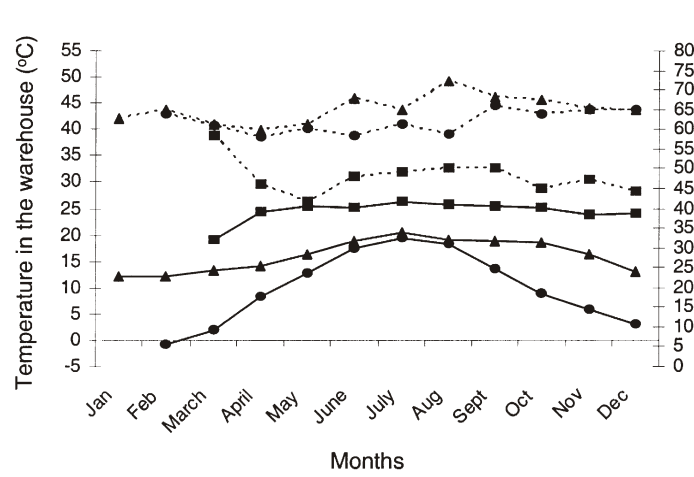

Figure 1a. Temperature (full lines) and relative humidity (dashed lines) in the warehouses from site A (circles), M (squares) and $\mathrm{T}$ (triangles)

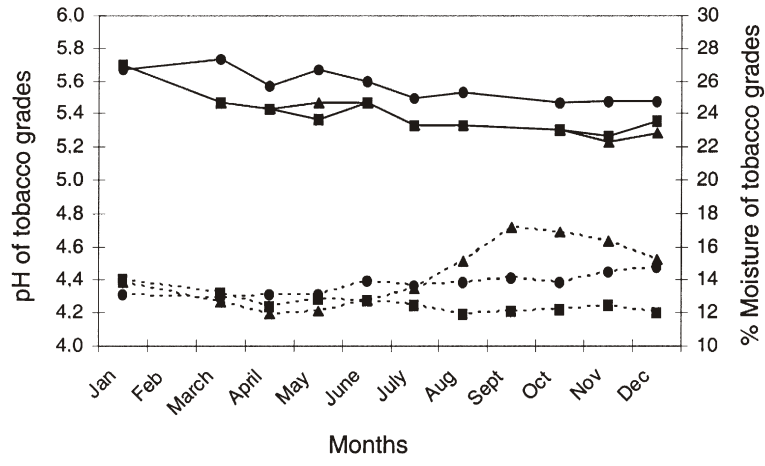

Figure 1b. pH (full lines) and moisture (dashed lines) average of the eleven tobacco grades from site A (circles), M (squares) and $\mathrm{T}$ (triangles)

ng for tobacco samples and 10-50 ng for isolate DNA) electrophoresed onto $8 \%$ polyacrylamide gels (acrylamide: $\mathrm{N}-\mathrm{N}$ '-methylenebisacrylamide $37.5: 1$ ) containing a linear denaturing gradient $(100 \%$ denaturing gel contained $7 \mathrm{M}$ urea and $40 \%$ deionized formamide). Electrophoresis was carried out using a Tris-acetate (TAE) running buffer (40 $\mathrm{mM}$ Tris- $\mathrm{HCl}, 40 \mathrm{mM}$ acetic acid, $1 \mathrm{mM}$ EDTA, $\mathrm{pH}$ 8.0) for $16 \mathrm{~h}$ at $100 \mathrm{~V}$ and $60{ }^{\circ} \mathrm{C}$. The gels were stained with ethidium bromide $(10 \mu \mathrm{g} / \mathrm{mL})$. A multistate discrete-characters parsimony method was used to determine relationship between DGGE profiles. For each profile, all bands were converted in $0-1$ values (absence - presence). The SEQBOOT program (PHYLIP package (version 3.65; http://evolution.genetics.washington.edu/phylip.html) was used to resample 1000 times the $0-1$ matrix (bootstrap and discrete morphology) and the PARS - Discrete character parsimony - program of the PHYLIP package was run. Only branched with more than $50 \%$ bootstrap were considered as significant.

The DGGE bands of interest were cut from the gel and the DNA was eluted in $500 \mu \mathrm{L}$ of $0.5 \mathrm{M} \mathrm{AcNH}_{4}, 10 \mathrm{mM}$, EDTA pH 8.0, $1 \mathrm{mM}$ and SDS $1 \%$ for $2-4$ hours at $37^{\circ} \mathrm{C}$. The suspension was centrifuged and the polyacrylamide was washed with $250 \mu \mathrm{L}$ of the elution buffer. DNA was precipitated with two volumes of ethanol. The DNA pellet was dissolved in $100 \mu \mathrm{L}$ water and precipitated again with

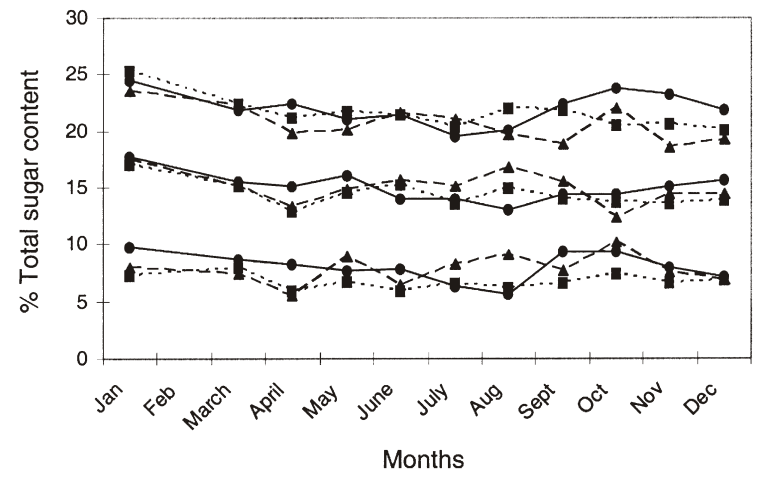

Figure 1c. Percentage of total sugar content of low (full lines), medium (small dashed lines) and high (dashed lines) sugar content samples from site $A$ (circles), $M$ (squares) and $T$ (triangles)

$1 / 10$ vol. sodium acetate $3 \mathrm{M}$ and two volumes of ethanol. This DNA was amplified as before with the $341 \mathrm{~F}$ (with no GC clamp) and $534 \mathrm{r}$ primers before sending to the sequencing service.

\section{RESULTS}

Changes in physico-chemical parameters during tobacco storage

The eleven tobacco grades were stored in three different locations - A, M and T - and were sampled for 12 months. Location A was in a country with a temperate climate, and the locations $\mathrm{M}$ and $\mathrm{T}$ in countries with a tropical climate. During the storage, the temperature at site A fluctuated more than at the two other locations ranging from $0{ }^{\circ} \mathrm{C}$ in winter to $18^{\circ} \mathrm{C}$ in summer (Fig. 1a). At site $\mathrm{M}$, the temperature stayed around $25^{\circ} \mathrm{C}$ for 9 months, and the tobacco was exposed to a lower degree of relative humidity compared with the two other locations. In the site $\mathrm{T}$, the temperature stayed between $15{ }^{\circ} \mathrm{C}$ and $20{ }^{\circ} \mathrm{C}$ but the tobacco was exposed to a higher degree of relative humidity (Fig. 1a).

The percentage of moisture in the A and $\mathrm{M}$ samples stayed relatively constant between 12 to $15 \%$ over the twelve months period (Fig. 1b). However the percentage of moisture in $\mathrm{T}$ samples increased from month $5(12 \%)$ to up to month $9(17 \%)$ and then decreased to $15 \%$ (Fig. 1b). The $\mathrm{pH}$ value of tobacco varied from 5.7 to 5.2 over the twelve months period for samples stored at all three locations (Fig. 1b).

The percentage of total sugars of the X2M sample (low sugar sample) remained under $10 \%$ at all three locations. On average, the percentage of total sugars of the H2M, X1C, MF2C and $\mathrm{H} 2 \mathrm{C}$ samples (medium sugar samples) ranged from 13 to $17 \%$ whereas, from 20 to $25 \%$ for the 01 , FS1C, $\mathrm{X} 1 \mathrm{C}, \mathrm{MF} 1 \mathrm{M}, \mathrm{H} 1 \mathrm{M}$ and $\mathrm{H} 1 \mathrm{samples}$ (high sugar samples) (Fig. 1c).

\section{Bacterial and fungal counts}

Bacterial counts remained stable and higher than fungal counts over the twelve months period of storage at all three locations (Figure 1d). Fungal counts at sites $\mathrm{M}$ and $\mathrm{T}$ 


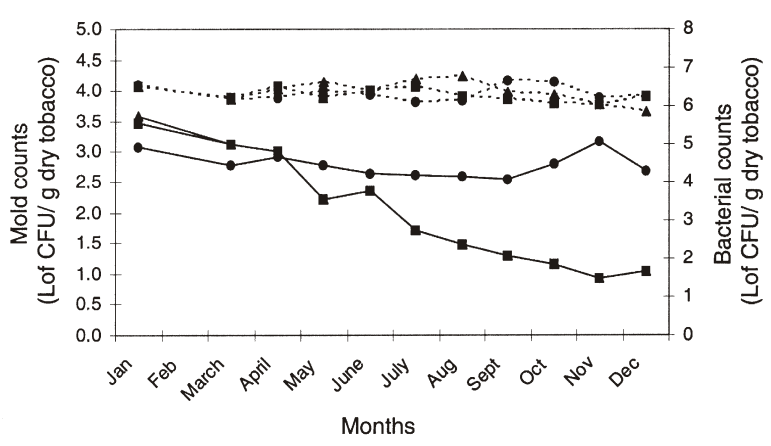

Figure 1d. Mold (full lines) and bacterial (dashed lines) counts average on a logarithmic scale for the eleven tobacco grades from site $A$ (circles), $M$ (squares) and $T$ (empty triangles)

decreased by two logs over the twelve months period of storage and remained stable at site A over the same period of time (Fig. 1d).

Effect of storage duration and location on the bacterial biota of tobacco grade

Changes in the microbial population of the eleven tobacco grades aged for twelve months at the three different locations were monitored by PCR-DGGE. More than 400 samples were processed and analyzed both for bacterial and fungal populations. Representative results are illustrated in Figures 2, 3 and 4. Figure 2 shows the results of the bacterial DGGE profiles of the eleven tobacco grades stored at site A after nine months storage. All samples had between 20 and 30 apparent bands. Changes were noticeable in the banding profiles. However these changes were limited to one or two bands per profiles as indicated in Figure 2. Although we noticed changes in the intensity of several specific bands, these variations were mostly minor, and were not taken into account as several factors related to experimental handlings could have produced such variations (see Discussion). All these bands were recorded and the resulted profiles were compared with a discrete character parsimony method combined with a bootstrap analysis for relationship significance. High relationships were found between all DGGE profiles (data not shown because bootstrap results were below 50\% [from 1000 bootstrap resamplings] for all samples) suggesting that the bacterial biota did not change substantially between tobacco grades. Similar results were observed with tobacco grades stored at sites $\mathrm{M}$ and $\mathrm{T}$ (data not shown).

We compared the DGGE profiles between the three locations after twelve months storage for three different grades (low, medium, high sugar content) (Fig. 3). The DGGE profiles were either identical or differed by only one band between the three locations. Only one noticeable band was prominent in the low sugar sample in the three locations (arrow $a$ in Fig. 3), and a different one in the medium and high sugar samples in the three locations (arrow $b$ in Fig. 3). As before, the discrete character parsimony method showed high relationships between DGGE profiles suggesting that the bacterial biota did not change substantially between the three locations.

We compared the DGGE profiles of grade MF2C located at site $\mathrm{A}$ and $\mathrm{M}$, and sampled after zero, eight, nine, eleven and twelve months storage (Fig. 4). There were very few changes in the different profiles that occurred during the twelve month storage in both locations. Similar DGGE profiles were also observed with samples from site $\mathrm{T}$ (data not shown). One band (arrow in Fig. 4) present in the samples aged for zero to nine months was less intense in tobacco aged for eleven and twelve months.

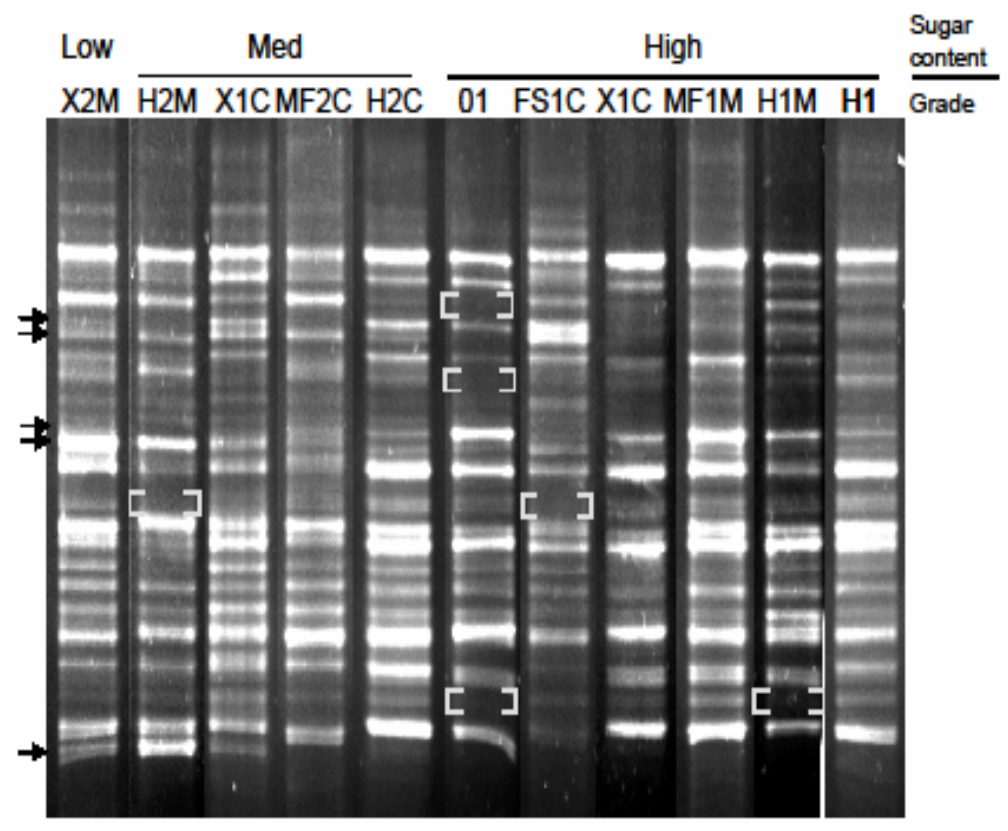

Figure 2. Bacterial profiles of the eleven tobacco grades stored at site A for nine months. Total DNA was extracted from the tobacco samples and the V3 region of the 16S rDNA was PCR-amplified. PCR products were separated by DGGE with a $20 \%$ to $70 \%$ denaturant gradient. Arrows indicate significant differences in the migration profiles of more than 2 samples. Other differences in the profiles are indicated by brackets. 


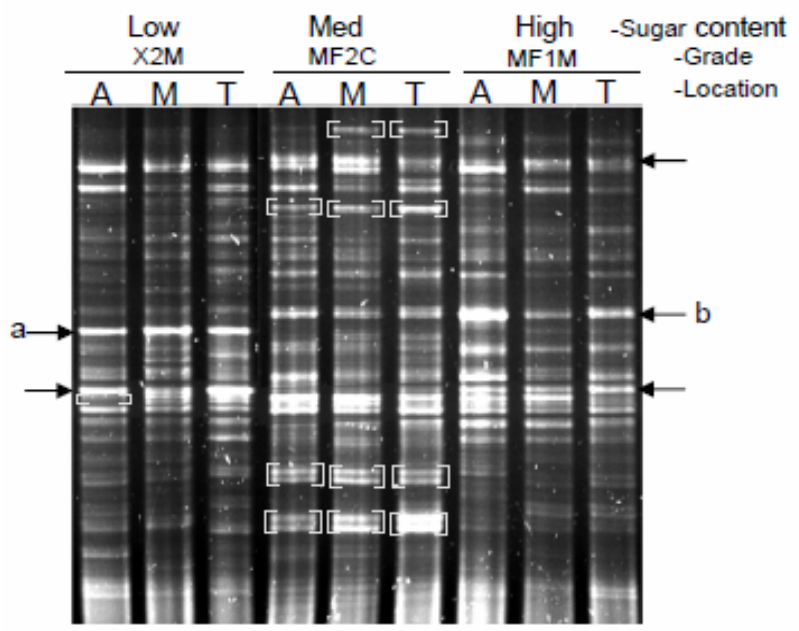

Figure 3. Effect of storage location on the bacterial biota of three tobacco grades stored for twelve months. PCR products were derived as described in legend of Figure 2 and were separated by DGGE with a $30 \%$ to $65 \%$ denaturant gradient. Arrows and brackets indicate significant differences in the migration profiles between samples.

\section{Identification of bacterial isolates}

Ten bacterial isolates were derived from grade MF2C stored at site $\mathrm{T}$ after twelve months. Total DNAs from the isolates and from the MF2C sample were extracted, and their 16S rDNA sequences were PCR amplified for DGGE

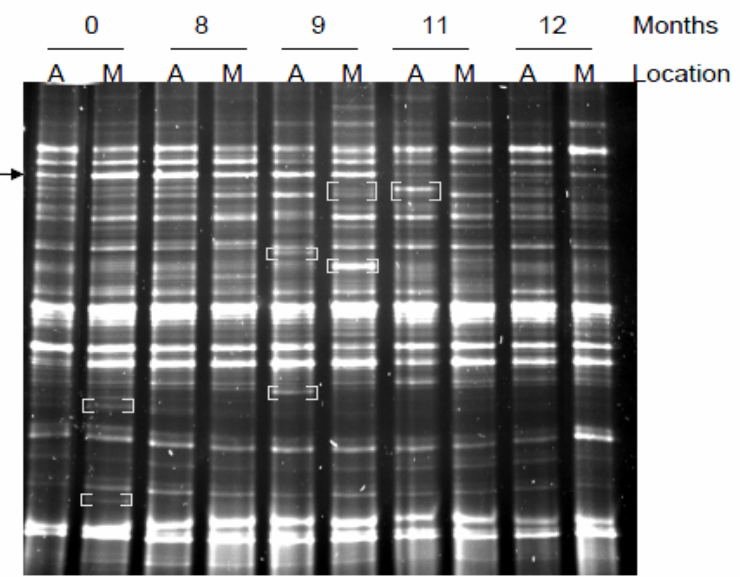

Figure 4. Effect of storage location over time on tobacco grade MF2C stored at A and M. PCR products were derived as described in legend of Figure 2 and were separated by DGGE with a $30 \%$ to $65 \%$ denaturant gradient. Arrow and brackets indicate significant differences in the migration profiles between samples.

experiments. The PCR products from the isolates were comigrated in DGGE with the PCR products from MF2C (Fig. 5). For most of the isolates, only one band was obtained and comigrated with one band of the MF2C DGGE migration profile. Longer $16 \mathrm{~S}$ rDNA sequences were derived from each isolate and their sequence determined. Comparisons with gene databases revealed

\section{$\begin{array}{lllllllllll}\text { MF2C } & \text { B1 } & \text { B2 } & \text { B3 } & \text { B4 } & \text { B5 } & \text { B6 } & \text { B7 } & \text { B9 } & \text { B10 } & \text { B11 }\end{array}$}

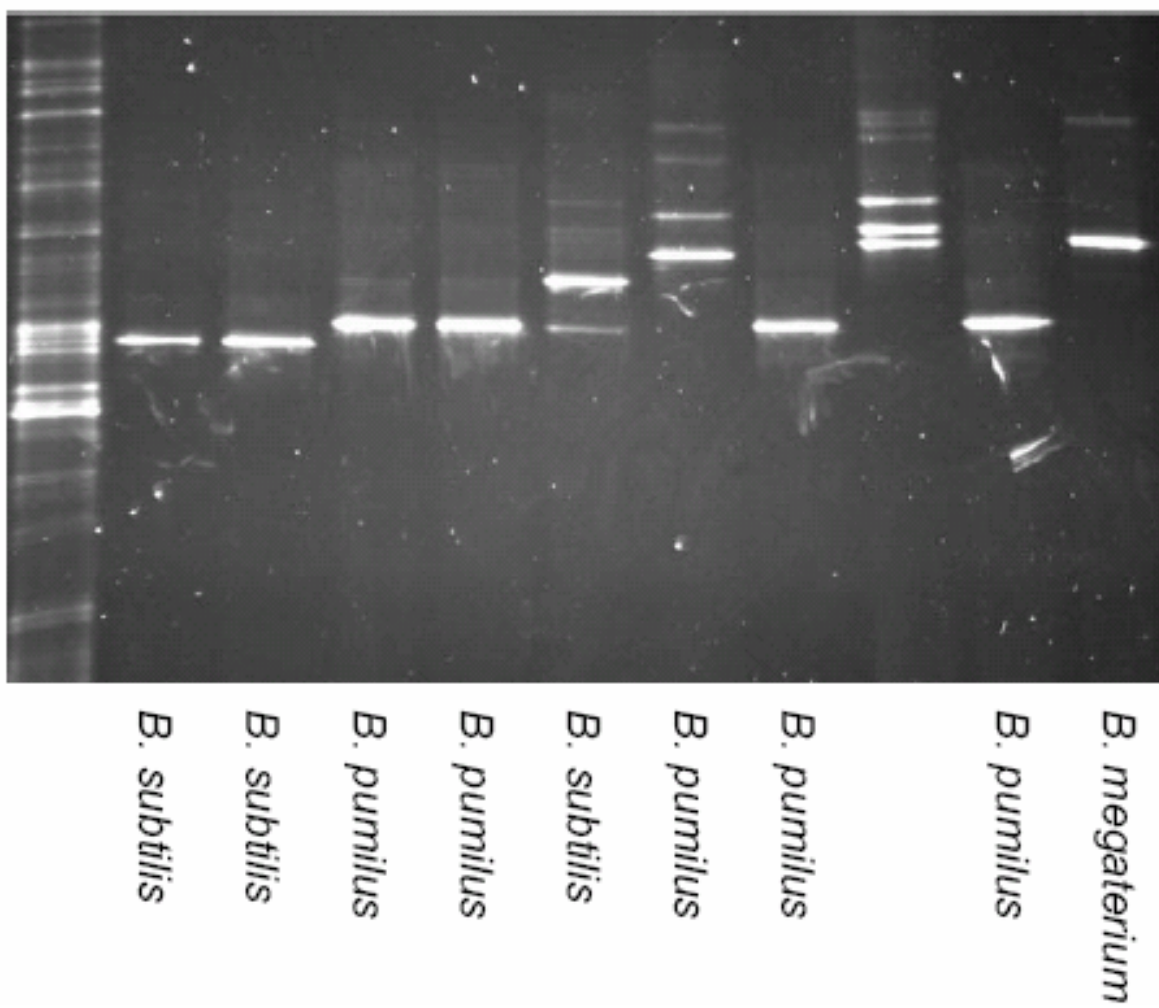

Figure 5. DGGE comigration profile between bacterial isolates and the tobacco grade MF2C. Isolates were derived from the tobacco grade MF2C aged for twelve months at the T location. PCR products were derived as described in legend of figure 2 and were separated by DGGE with a $30 \%$ to $65 \%$ denaturant gradient. MF2C; B1 to B11: Bacterial isolates. 
Table 1. List of PCR primers ${ }^{\text {a }}$

\begin{tabular}{|c|c|c|}
\hline Primer & Sequence $\left(5^{\prime}-3^{\prime}\right)$ & References \\
\hline \multicolumn{3}{|l|}{$16 \mathrm{~S}$ rDNA sequences } \\
\hline $27 f$ & AGAGTTTGATCMTGCTCAG & (10) \\
\hline $1525 r$ & AAGGAGGTGATCCARCCGCA & $(10,11)$ \\
\hline $341 \mathrm{f}-\mathrm{GC}$ & $\begin{array}{l}\text { CGCCCGCCGCGCGCGGCGGGCGGGGCGGG } \\
\text { GGCACGGGGGGCC-TACGGGAGGCAGCAG }\end{array}$ & $(2)$ \\
\hline $534 r$ & ATTACCGCGGCTGCTGG & (2) \\
\hline \multicolumn{3}{|l|}{$18 \mathrm{~S}$ rDNA sequences } \\
\hline NU-ssu-1196-5' & GGAAACTCACCAGGTCCAGA & (8) \\
\hline NU-ssu-1536-3'-GC & $\begin{array}{l}\text { CGCCCGCCGCGCGCGGCGGGCGGGGCGGGG } \\
\text { GCACGGGGGG-ATTGCAATGCYCTATCCCCA }\end{array}$ & (8) \\
\hline Euk-82F & GAAACTGCGAATGGCTC & (12) \\
\hline Uni-1392r & ACGGGCGGTGTGTRC & (10) \\
\hline
\end{tabular}

${ }^{a}$ The $341 \mathrm{f}-\mathrm{GC} / 534 \mathrm{r}$ and NU-ssu-1196-5'/ NU-ssu-1536-3'-GC sets of primers were used for PCR-DGGE experiments, and the $27 \mathrm{f} / 1525 \mathrm{r}$ and Euk-82F/Uni1390r sets of primers to generate longer rDNA PCR products. $341 \mathrm{f}-\mathrm{GC} / 534 \mathrm{r}$ and $27 \mathrm{f} / 1525 \mathrm{r}$ are universal bacterial sets of primers. NU-ssu-1196-5'/ NU-ssu-1536-3' target most fungi, and Euk-82F/Uni1390r most of Eukarya.

Table 2. Most probable affiliation of bacterial isolates based on 16S rDNA gene sequences

\begin{tabular}{|c|c|c|c|}
\hline Isolate & Species & GenBank accession number & $\%$ identity $^{a}$ \\
\hline B1 & Bacillus subtilis & EU500931 & $99.7 \%$ \\
\hline B2 & Bacillus subtilis & DQ676957 & $100 \%$ \\
\hline B3 & Bacillus pumilus & EF173329 & $100 \%$ \\
\hline B4 & Bacillus pumilus & EF173329 & $99.9 \%$ \\
\hline B5 & Bacillus subtilis & EF423592 & $100 \%$ \\
\hline B6 & Bacillus pumilus & EF465530 & $100 \%$ \\
\hline B7 & Bacillus pumilus & EF173329 & $99.7 \%$ \\
\hline B9 & not determined & & \\
\hline B10 & Bacillus pumilus & EF488975 & $100 \%$ \\
\hline B11 & Bacillus megaterium & EF114346 & $99.8 \%$ \\
\hline
\end{tabular}

aldentity is based on approximately the first $1000 \mathrm{nt}$ of the $16 \mathrm{~S}$ rDNA genes with the respective species

that all isolates (except isolate B9 which was composed of more than one species) were related to Bacillus subtilis, $B$. pumilus or $B$. megaterium with $>99 \%$ sequence identity (Table 2).

PCR-amplified 16S rDNA sequences of the microbial fractions of nine tobacco grades were separated by DGGE. DNA from seventeen bands was retrieved from the gel, reamplified and sequenced. Nine of the seventeen DNA generated readable sequences of 150-200 nucleotides. Comparison of these readable sequences with gene databases provided affiliation at least to the genus level: Erwinia, Pseudomonas, Enterobacter, Xanthomonas, Pantoea, Klebsiella and Rheinheimera (gamma Proteobacteria); Bradyrhizobiacea (alpha Proteobacteria); and Bacillus (Bacillales).

Effect of storage duration and location on the fungal biota of tobacco grade

18S rDNA sequences were PCR amplified with primers specific for the main fungal lineages such as the Ascomycota and the Basidiomycota. All the DGGE migrating profiles were very simple with one dominating band that was observed mostly in all samples (Fig. 6), with some profiles having also low intensity bands. The PCR products representative of the dominating band were all related to Aspergillus niger at more than $99 \%$ on 324 nucleotides.

Fungal isolates were derived from the tobacco microbial fractions. Total DNAs from seven of them and from tobacco samples were extracted, and their 18S rDNA sequences were PCR amplified for DGGE experiments. All the isolates generated one DGGE band that comigrated with the dominating DGGE band of the tobacco samples. Longer 18S rDNA sequences (app. $900 \mathrm{nt}$ ) were derived from each isolate and their sequence determined. Sequences of isolates $\mathrm{m} 5, \mathrm{~m} 7$ and $\mathrm{m} 8$ from sample MF1M were identical, and were related to the genus Aspergillus with the closest species being niger. Sequences of isolate $\mathrm{m} 6$ from sample MF1M and isolates $\mathrm{m} 13$ and $\mathrm{m} 15$ from sample H1M had two nucleotides differences with isolate m5, and were also related to the genus Aspergillus with the closest species being oryzae. Finally, sequence of isolate $\mathrm{m} 14$ from sample H1M had a 5-nucleotide difference with isolate $\mathrm{m} 5$ and a 3 -nucleotide difference with isolate m6. It was also related to the genus Aspergillus with the closest species being unguis.

\section{DISCUSSION}

Tobacco processing involves curing, drying the tobacco leaves up to $60-70{ }^{\circ} \mathrm{C}$, and aging, i.e. leaf storage for 


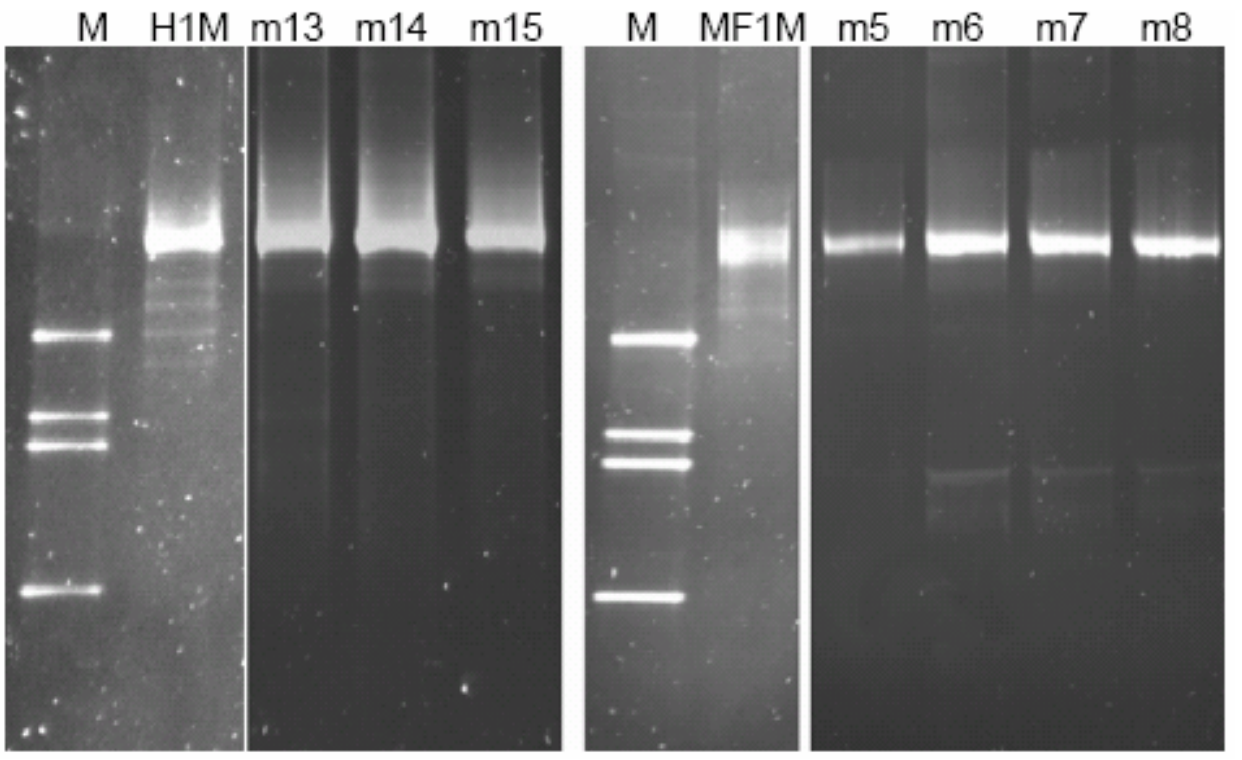

Figure 6. DGGE comigration profile between fungal isolates and tobacco grades H1M and MF1M. Isolates $\mathrm{m} 13, \mathrm{~m} 14$ and $\mathrm{m} 15 \mathrm{were}$ derived from the tobacco grades $\mathrm{H} 1 \mathrm{M}$ and $\mathrm{m} 5$ to $\mathrm{m8} \mathrm{MF1M}$, both stored at site A. Total DNA was extracted from tobacco samples or fungal isolates, and part of the $18 \mathrm{~S}$ rDNA was PCR-amplified. PCR products were separated by DGGE with $30 \%$ to $65 \%$ denaturant gradient. M: DGGE migration marker. The marker was composed of PCR products derived from 16S rDNA sequences of (top to button) Staphylococcus aureus, Pseudomonas aeruginosa, Enterococcus faecalis and Escherichia coli.

several months. In our study, we investigated if changes of microbial population occurred during aging of tobacco at three different locations with culture-independent methods. We used PCR-DGGE to monitor changes of the bacterial and fungal biota of eleven tobacco grades aged for twelve months at the three different locations. One of the key steps in succeeding at amplifying PCR products from bacterial and fungal DNA was the maceration of the tobacco plant to release the associated microorganisms to avoid interference of microbial DNA with tobacco DNA. In the two reports on monitoring microbial populations from tobacco by PCR-DGGE, Di GIACOMO et al. (3) and ZHAO et al. (1) successfully used similar approach to separate the microbial DNA fraction from the tobacco DNA.

In all samples examined (around 400), between 20 and 30 bacterial DGGE migrating bands were observed for each sample. The number of bands that we observed was similar to the one observed in the DGGE profiles reported by ZHAO et al. (1) but higher than the number of bands reported by DI GIACOMO et al. (3) who found approximately 15 to 20 DGGE bands for some of their samples. Changes in the bacterial DGGE profiles were observed in several samples (as illustrated by representative DGGE in Figures 2, 3 and 4) but were limited to the presence/absence of one to two bands, which suggests that small changes occurred in the bacterial population. However, these changes could have been caused by the heterogeneity of the tobacco sampled. Indeed, variation in the DGGE profiles involving 2-3 bands were observed from three samplings of the original tobacco before storing (data not shown). Using a discrete character parsimony method, high relationships were found between all DGGE profiles, which suggest that no substantial changes occurred in the bacterial population of the different tobacco grades during their storage. Furthermore, neither of the location of storage, moisture content, $\mathrm{pH}$, sugar content nor the bacterial counts of the tobacco grades caused any changes on the bacterial biota even though some of these parameters varied (Figure 1a, 1b, 1c and 1d). These results support the idea that tobacco storage is not a biologically dynamic process. For instance, the moisture of the tobacco was relatively low (varying between $12-17 \%$ ), which did not favor bacterial metabolism. This contrasts with the work of ZHAO et al. (1) who observed significant changes in the DGGE profiles between three tobacco varieties. Each variety showed no changes in their first six months of aging, but presented different patterns after nine months. DI GIACOMO et al. (3) monitored the evolution of the microbial population of a cigar tobacco during its fermentation. They also measured significant changes in the DGGE profiles during the fermentation process. However, these changes were expected as the tobacco went through a process more biologically dynamic than tobacco aging.

In our DGGE profiles, the only variations noticed were in intensity of certain bands from one profile to the other. These could be attributed to variation in the cell concentration of the respective bacterial species present at the time of sampling. However, we did not consider the intensity of the bands as a criterion in the discrete character parsimony method because PCR-DGGE is at most a semi-quantitative method, and several factors could have influenced the intensity of these bands. First, the extracted DNA is from a mixture of microbial genomes, each may have had different number of copies of rDNA genes. Second, the primer hybridization and the PCR amplification can be influenced by the corresponding rDNA sequence. In our study, there were several low intensity bands that may have been influenced by the above factors.

In parallel to culture-independent methods, we cultured on BHI media several bacterial isolates from the microbial fractions of some tobacco grades. Ten of them were analyzed by PCR-DGGE and a particular DGGE band was associated to Bacillus subtilis, B. pumilus or B. megaterium. Affiliation of other bacterial isolates revealed the presence of gamma- 
Proteobacteria associated to the genera of Klebsiella, Enterobacter, Erwinia and Cronobacter. Other species such as Bacillus licheniformis and Staphylococcus pasteuri were identified (data not shown). Sequences from DNA extracted from DGGE bands were also affiliated to Klebsiella, Enterobacter, Erwinia and Bacillus. These results confirmed the potential of PCR-DGGE for monitoring specific bacterial species not isolated by culture-dependent methods.

ZHAO et al. (1) sequenced the five most dominant DGGE bands that were related to Bacillus megaterium (Bacillales), Bacteriovorax sp. (delta-Proteobacteria) and three uncultured bacteria; one being affiliated to alphaProteobacteria. Di GiACOMO et al. (3) sequenced the most dominant DGGE bands but also DNA from single-strand conformational polymorphism bands. They were affiliated to Lactobacillus, Bacillales (such as B. pumilus, B. subtilis, B. licheniformis), Actinobacteria and to Marinilactibacillus. The same authors also derived bacterial isolates with high prevalence to Bacillaceae; the most numerous ones were related to B. pumilus, B. subtilis and B. licheniformis. Combined with our results, the three reports showed the constant occurrence of Bacillus species on flue-cured tobacco. This is not surprising as these bacteria can form thermotolerant spores, and consequently can survive in harsh environments such as those encountered in tobacco curing (high temperature) and aging (low humidity).

We used a set of primers designed to amplify rDNA from all four major phyla of fungi: Ascomycota, Basidiomycota, Chytridomycota and Zygomycota (8). Despite this broad specificity, only one dominate band was found in the DGGE profiles of most of the tobacco samples. This suggests that a high proportion of fungi related to Aspergillus were present. This was confirmed by the $18 \mathrm{~S}$ rDNA sequences of isolates derived from our tobacco and all belonged to the genus Aspergillus.

No conclusion can be drawn on the origin of the microorganisms found on tobacco and whether they are biologically active or not. In other words, the analyzed nucleic acids were derived from microorganisms that were active in situ or from spores present with the tobacco from the high temperature curing and subsequent low moisture environment. Functionality of Bacillus species during tobacco fermentation has however been proposed by DI GiACOMO et al. (3).

In conclusion, the PCR-DGGE method allowed us to monitor a broad spectrum of microbial species as one set of primers targeted most bacteria and the other most fungi. Even if the environmental conditions of storage (Figure 1a), the microbial counts and the physico-chemical parameters varied between the three sites (Figure $1 \mathrm{~b}$ to $1 \mathrm{~d}$ ), only minor differences in the microbiota were detected between storage location and duration. Identifying which microorganisms correspond to the DGGE bands will allow monitoring only specific species during further tobacco processing (e.g. curing, aging, fermentation and manufacturing). Finally, our work confirmed that Bacillus and Aspergillus species are the predominant bacteria and mold, respectively found in flue-cured aging tobacco, as previously reported (9). These two genera may be present in the stored tobacco environment in the sporulated forms that have no relation to a functioning microbial community.

\section{ACKNOWLEDGEMENTS}

We thank Ron Bandur, Georges Howard, Joanne Joly and the Laboratory Services Group of ITCAN for their professional advice and help to collect, process and analyze tobacco samples

\section{REFERENCES}

1. Zhao, M., B. Wang, F. Li, L. Qiu, F. Li, S.Wang, and J. Cui: Analysis of bacterial communities on aging fluecured tobacco leaves by $16 \mathrm{~S}$ rDNA PCR-DGGE technology; Appl. Microbiol. Biotechnol. 73 (2007) 1435-1440.

2. Muyzer, G., E.C. De Waal, and A.G. Uitterlinden: Profiling of complex microbial populations by denaturing gradient gel electrophoresis analysis of polymerase chain reaction amplified genes coding for 16S rRNA; Appl. Environ. Microbiol. 59 (1993) 695-700.

3. Di Giacomo, M., M. Paolino, D. Silvestro, G. Vigliotta, F. Imperi, P. Visca, P. Alifano, and D. Parente: Microbial community structure and dynamics of dark fire-cured tobacco fermentation; Appl. Environ. Microbiol. 73 (2007) 825-837.

4. Welty, R.E. and G.B. Lucas: Fungi isolated from fluecured tobacco at time of sale and after storage; Appl. Microbiol. 17 (1969) 360-365.

5. Welty, R.E. and L.A. Nelson: Growth of Aspergillus repens in flue-cured tobacco; Appl. Microbiol. 21 (1971) 854-859.

6. Tso, T.C.: Seed to Smoke; in: Tobacco: Production, Chemistry, and Technology edited by D. Layten Davis and M.T. Nielsen, Blackwell Science, Inc. Malden, MA., 1999, pp. 1-31.

7. CORESTA: Determination of reducing substances in tobacco by continous flow analysis; Method No37 (1994).

8. Borneman, J. and R.J. Hartin: PCR primers that amplify fungal rRNA genes from environmental samples; Appl. Environ. Microbiol. 66 (2000) 4356-4360.

9. Qiu, L., M. Zhao, X. Yue, W. Qi, and W. Zhang: Isolation and identification of the microflora on tobacco leaves during the natural fermentation of flue-cured tobacco; Tob. Sci. Technol. 3 (2000) 14-17.

10. Lane, D.J.: 16S/23S rRNA sequencing; in: Nucleic Acid Techniques in Bacterial Systematics, edited by E. Stackebrandt and M. Goodfellow, John Wiley \& Sons, Chichester, U.K., 1991, pp. 115-175

11. Edwards, U., T. Rogall, H. Blöcker, M. Emde, and E.C. Böttger: Isolation and direct complete nucleotide determination of entire genes: characterization of a gene coding for $16 \mathrm{~S}$ ribosomal RNA; Nucleic Acids Res 17 (1989) 7843-7853.

12. Brown, P.B. and G.V. Wolfe: Protist genetic diversity in the acidic hydrothermal environments of Lassen volcanic national park, USA; J. Eukaryotic Microbiol. 53 (2006) 420-431.

\author{
Address for correspondence: \\ André Morin \\ Imperial Tobacco Canada, Montreal, QC, H4C 3P6 \\ E-mail:amorin@itl.ca
}

